\title{
Microbial and Sensory Assessment of Sand Smelt Fish Burger and Finger during Frozen Storage
}

\author{
Adel A. El-Lahamy ${ }^{1, *}$, Khalil I. Khali $^{2}$, Shaban A. El-Sherif ${ }^{1}$ and Awad A. Mahmud ${ }^{2}$ \\ ${ }^{1}$ National Institute of Oceanography and Fisheries, Fish Processing Technology Laboratory, Cairo, Egypt \\ ${ }^{2}$ Food Science and Technology Department, Faculty of Agriculture, Fayoum University, Fayoum
}

\begin{abstract}
The current study aimed to assess the microbiological safety and sensory quality of fish burger and finger made from sand smelt fish (Atherinahepsetus) which was found unacceptable from consumers. The substitution material (soybean flour (SF) and minced boiled potatoes (MBP)) were used by different levels in this investigation to improve the sensory evaluation of produced fish products. Total bacterial count (TBC) values for burger and finger samples gradually declined till the day $45^{\text {th }}$ then increased in the later period of frozen storage. Yeast and Molds growth were not detected during the frozen storage over the entire period of 90 days storage, except for zero time the score values of the quality attributes: color, taste, odor and texture, as well as overall acceptability of sand smelt fish burgers and fingers, slightly declined during frozen storage. The filling materials SF and MBP used in the production of fish products showed an observed effect in maintaining the sensory qualities of the products for 90 days of frozen storage. It can be concluded that sand smelt fish products maintained good microbial and sensory quality at the end of 90 storage period in the freezer, opening an opportunity for this good nutritious protein source to be used as a daily food.
\end{abstract}

Keywords: Microbiology, Sensory evaluation, Sand smelt, Fish burger and fish finger.

\section{INTRODUCTION}

Fish and fishery products have been recognized as very important sources for human nutrition. Fishes are characterized by their high contents of high quality, easily digestible protein and essential amino acids. Moreover, they are low in the saturated fatty acids and contain considerable amounts of the unsaturated fatty acids, especially omega- 3 fatty acids, which are regarded as oxidation preventive compounds, among other health benefits. The oil-soluble vitamins are known to be present in fish muscle. Also, they are a good source of several minerals, particularly fluorine and iodine [1].

In Egypt, the total quantity of catch fish recorded $1,706,273$ tones, while the total quantity of Exports and Imports of fish were 47,812 and 311,068 tones, respectively. Annual average share per capita of fish was $21.64 \mathrm{~kg}$ [2]. Sand smelt (Atherinaboyeri) is a common species in the Mediterranean Sea and has shown distribution from north-east Atlantic to northwest coast of Scotland. Also, this species lives in the Black Sea, Aegean Sea, Marmara Sea, Aral and Caspian Sea [3]. Global changes in consumer lifestyle, marked by increasing demand for nutritional and healthy food products, have spurred the continuing rise in demand for fresh and convenient ready-to-cook fish and fishery

"Address correspondence to this author at the National Institute of Oceanography and Fisheries, Fish Processing Technology Laboratory, Cairo, Egypt; Tel: +201100425093;

E-mail: adelammar11@yahoo.com products. This rising demand for ready to eat fish meals, instead of plane frozen fish, requires the use of preservation procedures that can add value and reduce fishery losses [4]. Freezing preservation of food has been used for thousands of years as it results in high product quality with a huge increase on shelf life, as long as frozen temperatures are kept along the delivery chain. It is a usual method to preserve commercial fish since it preserves freshness inhibiting chemical and microbiological degradation, and is an excellent method of preserving the sensory attributes of fish flesh during long periods of time [5]. Microbiological quality of fresh and frozen fish can be judged using several criteria [6]. For high quality fresh fish, the number of bacteria present in the surface varies from 3 to $4 \mathrm{log}$ cful g. On gills, counts are normally one or two orders higher, and intestinal counts can reach 9 log cfu/ g. [78] reported that the reduction in microorganisms by the TVC (Total Viable Count) during freezing may be due to the damage of bacteria cells caused by grown crystals. About $10^{4}-10^{6} \mathrm{TVC} / \mathrm{g}$ is considered an acceptable figure in the Australian meat industry [9]. Therefore, the overall objective of this study was to:

1. Examine the microbial safety of sand smelt fish burger and finger during frozen storage at $-18^{\circ} \mathrm{C}$ for 90 days.

2. 2- Determine the changes in sensory evaluation of sand smelt frozen fish products stored at $18^{\circ} \mathrm{C}$ for a 3 month period. 


\section{MATERIALS AND METHODS}

Fish

Fresh sand smelt (bassaria) fish (Atherinahepsstia) was obtained from Qarun Lake at Fayom Governorate, Egypt during April, 2017. About $25 \mathrm{~kg}$ of fish were transported in ice to the laboratory of Fish Research Station (at Shakshouk, Fayoum), National Institute of Oceanography and Fisheries (NIOF).

\section{Burgers and Fish Fingers}

\section{Filling Materials}

Soybean flour (SF) and Minced boiled potatoes (MBP) were used as filling materials in the processing of fish products. SF was obtained from Food Technology Research Institute, Agriculture Research Center at Giza Governorate, Egypt. MBP was prepared by boiling potatoes for $15 \mathrm{~min}$, then peeled and minced.

\section{Ingredients}

The ingredients included sunflower oil, starch, wheat flour, sugar, salt, onion, garlic and spices were obtained from the local market.

\section{Preparation of Fish}

On arrival at the laboratory, fish was beheaded, gutted and washed gently with tap water. The edible portion of fish was soaked in $1 \%$ salt solution contained $0.5 \%$ acetic acid for $5 \mathrm{~min}$ to remove the fishery odor and taste, then drained off and minced using an electric meat mincer (Braun plus 1300). A portion of the minced fish was used in the chemical analysis and the microbial examination of the raw material (sand smelt fish). The remaining quantity was divided into two portions, kept to process fish products into burger and finger.

\section{Fish Burger Formulation and Processing}

Control fish burger (no filling material) was composed of $75 \mathrm{~g}$ of minced fish and $25 \mathrm{~g}$ of the ingredients mixture for $100 \mathrm{~g}$ batter as shown in Table (1) which indicates the recipe of sand smelt burger as mentioned by [10]. The experimental burgers were formulated by using SF and MBP as filling materials. Each of the two filling materials was used at levels of 10,15 and $20 \%$ of weight of the minced fish used. The experimental formulated samples were made by replacing the minced fish with the filling material at the desired level as illustrated in Table (1). All the formulations were needed by hand until homogeneous dough was obtained. Portions of $50 \mathrm{~g}$ were shaped (8.5 $\mathrm{cm}$ diameter and $1.0 \mathrm{~cm}$ thickness) by manually operated forming machine (NOAW- Affetacrane, Italy). Burger samples were packed in polyethylene bags and stored at $-18^{\circ} \mathrm{C}$ until required for analysis.

\section{Fish Fingers Formulation and Processing}

Fish fingers were prepared as described by [11-12]. Control fish fingers (without filling material) were composed of $93.5 \mathrm{~g}$ of minced sand smelt fish and $6.5 \mathrm{~g}$ of the ingredients mixture as shown in Table (2). The experimental fingers were formulated by using the filling materials i.e. SF and MBP at levels of 10, 15 and $20 \%$ of the minced fish as described in burger formulation. The formulated samples were made by replacing the minced fish with the filling materials at the tested levels (Table 1). The minced fish was mixed with the ingredients and the mixture was homogenized until smooth dough was obtained. The dough was shaped into fingers and frozen at $-18 \mathrm{C}$ for $2 \mathrm{~h}$ before battering. The frozen fish fingers were rapidly coated with batter solution ( 3 parts of water plus 2 parts contained $94 \%$ maize flour, $2 \%$ skim milk, $2 \%$ egg yolk and $2 \%$ salt) and then they were rubbed with ground crumb.

Table 1: Substitution Levels of the Filling Materials (SF and MBP) used in the Preparation of Sand Smelt Fish Burger and Fingers

\begin{tabular}{|c|c|c|c|c|}
\hline \multicolumn{2}{|c|}{ Fish Burger } & \multicolumn{2}{c|}{ Fish Fingers } & \multirow{2}{*}{ Substitution Level (\%) } \\
\cline { 1 - 4 } Minced Fish (g) & (SF) or (MBP)(g) & Minced fish (g) & (SF) or (MBP) (g) & 0 \\
\hline \hline 75.00 & - & 93.50 & - & 10 \\
\hline 67.50 & 7.50 & 84.15 & 9.35 & 15 \\
\hline 63.75 & 11.25 & 79.47 & 18.03 & 20 \\
\hline 60.00 & 15.00 & 74.80 & & 20 \\
\hline
\end{tabular}

SF: Soybean flour, MBP: Minced boiled potato. 
Table 2: Recipes of Sand Smelt Fish Burger and Fingers

\begin{tabular}{|c|c|c|c|}
\hline \multicolumn{2}{|c|}{ Fish Burger } & Fish Fingers \\
\hline \hline Ingredients & $\%$ & Ingredients & Fish mince \\
\hline Fish mince & 75.00 & Salt & 1.50 \\
\hline Vegetable oil & 9.00 & Sugar & 3.00 \\
\hline Starch & 8.00 & Wheat flour & 3.00 \\
\hline Salt & 2.30 & Cumin & 0.24 \\
\hline Sodium bicarbonate & 0.40 & Onion & 0.24 \\
\hline Onion & 2.50 & Garlic powder & 0.24 \\
\hline Garlic & 0.50 & Black pepper & 0.24 \\
\hline Polyphosphate & 0.30 & Thyme & 0.04 \\
\hline
\end{tabular}

"Spices mixture composed of $32 \%$ black pepper, $22.5 \%$ coriander, $15 \%$ cumin, $10 \%$ cardamom, $9 \%$ red pepper, $7.5 \%$ cubeb and $4 \%$ clove.

\section{Microbiological Analysis}

$10 \mathrm{~g}$ of fish sample were aseptically weighted and homogenized with $90 \mathrm{ml}$ of sterile saline water for 1 min for each treatment. The homogenized samples were serially diluted using $9 \mathrm{ml}$ sterile saline for bacteriological analysis. Total bacterial count (TBC), Yeasts and Molds count were examined along the 90 days storage period.

\section{Total Viable Count (TBC)} [13].

TBC was determined by using nutrient agar medium

\section{Yeasts and Molds Count}

Yeasts and molds counts were enumerated on malt agar as mentioned by [14].

\section{Sensory Evaluation}

Sensory evaluation of raw, smoked and Mullet fish and fried tilapia was performed by ten panelists chosen from the staff members of Shakshouk Research Station (NIOF). The organoleptic properties of raw, processed products were tested according the scale described by [15] as follows:

\begin{tabular}{|c|c|c|}
\hline $1-2$ rejected & 3-4 accepted & $5-6$ good \\
\hline \multicolumn{2}{|c|}{$7-8$ very good } & cellent \\
\hline
\end{tabular}

The characteristics of color, odor, taste, texture and overall acceptability were tested.

\section{Statistical Analysis}

The statistical analysis of the results obtained was carried out according to SPSS version 16 software program 2007. Means and standard deviation (SD) measured by L.S.D at $5 \%$ level of significant.

\section{RESULTS AND DISCUSSION}

\section{Microbiological Quality}

The microbiological changes during storage of fish and fishery products are responsible for progressive decline of organoleptic quality caused mainly by the microbial growth and metabolism [16]. Bacteria and fungi spoilage have an important role in the quality and safety of fishery products.

Sand smelt fish burgers and fingers were examined microbiologically for total bacterial count, as well as mold and yeast count, immediately after processing and during frozen storage at $-18 \mathrm{C}$ for 90 days. As shown in Table (3) the initial total bacterial counts for control, $15 \%$ SF and 15\% MBP burger samples before storage were found to be $3.25 \pm .115,3.71 \pm .150$ and $4 \pm .087 \mathrm{cfu} / \mathrm{g}$, respectively. Also, the initial values of TBC for finger samples were found to be slightly higher than in burger samples and determined by $3.61 \pm .115$, $4.11 \pm .063$ and $4.44 \pm .196 \mathrm{cfu} / \mathrm{g}$ for control, $20 \%$ SF and $15 \%$ MBP finger samples, respectively. These findings indicated the microbiological good quality of the fresh samples of Sand smelt product since the value of TBC is considerably lower than the maximum limit $(7 \mathrm{log}$ cfu/g) of microbiological criteria for fresh fish given by the International Commission Microbiological Specification for Food [17]. These results could be attributed to the good freshness of sand smelt fish used in the production, the good quality of the ingredients and the sanitary conditions applied during preparation, processing and handling the products. 
The results presented in Table (3) show the microbiological changes in respect of TBC of sand smelt fish burgers and fingers during frozen storage. It was observed that TBC values for burger and finger samples gradually declined till the day $45^{\text {th }}$ then increased in the later period of frozen storage. At the end of 90 days storage TBC values reported for burger and finger samples ranged from $3.89 \pm .080$ to $4.74 \pm .080 \mathrm{cfu} / \mathrm{g}$. The increase of TBC may be due to the multiplication of microbial counts that can able to grow under freezing conditions [18]. While the reduction in TBC may be due to the damage of bacterial cells caused by grown ice crystals [19]. [20] reported that freezing generally causes a reduction in bacterial count and the number will continue, in most cases, to fall during frozen storage. Our data indicate that even after 90 days of frozen storage the total bacteria counts in sand smelt fish products did not exceed the recommended limit. Similar findings were reported by [12-21].
Data given in Table (4) show mold and yeast counts in Sand smelt fish products during frozen storage. The initial counts of mold and yeast in the different samples ranged from $2.01 \pm .092$ to $2.84 \pm .196 \mathrm{cfu} / \mathrm{g}$ at zero time storage. During the frozen storage over the entire period of 90 days no mold and yeast could be found by microbiological analysis. Similarly, [21] found no growth of microorganisms during frozen storage of some fish products at temperature below $-18^{\circ} \mathrm{C}$.

\section{Sensory Quality Attributes}

Sensory quality attributes of fish and fishery products may undergo some changes during storage, which will considerably affect the consumer acceptability of such products. Therefore, fish products made from sand smelt fish were evaluated for their organoleptic characteristics at intervals of 15 days during frozen storage for 90 days, to assess the storage stability of such products. Burger and fingers

Table 3: Changes in Total Bacterial Count (TBC) of Sand Smelt Fish Products during Frozen Storage at $-18^{\circ} \mathrm{C}$

\begin{tabular}{|c|c|c|c|c|c|c|}
\hline \multirow{2}{*}{ Storage Period (day) } & \multicolumn{3}{|c|}{ Fish Burger } & \multicolumn{3}{c|}{ Fish Finger } \\
\cline { 2 - 7 } & Control & SF (15\%) & MBP (15\%) & Control & SF (20\%) & MBP (15\%) \\
\hline \hline 0 & $3.25 \pm .115$ & $3.71 \pm .150$ & $4 \pm .087$ & $3.61 \pm .115$ & $4.11 \pm .063$ & $4.44 \pm .196$ \\
\hline 15 & $3.19 \pm .086$ & $3.65 \pm .086$ & $3.94 \pm .115$ & $3.54 \pm .138$ & $4.06 \pm .034$ & $4.49 \pm .109$ \\
\hline 30 & $3.11 \pm .063$ & $3.49 \pm .051$ & $3.85 \pm 0.86$ & $3.33 \pm .190$ & $4.00 \pm .115$ & $4.34 \pm .196$ \\
\hline 45 & $3.00 \pm .057$ & $3.35 \pm .202$ & $3.79 \pm .086$ & $3.15 \pm .086$ & $3.91 \pm .178$ & $4.11 \pm .063$ \\
\hline 60 & $3.21 \pm .121$ & $3.39 \pm .086$ & $3.84 \pm .138$ & $3.54 \pm .138$ & $3.9 \pm 7.213$ & $4.17 \pm .098$ \\
\hline 75 & $3.74 \pm .089$ & $3.44 \pm .127$ & $3.94 \pm .138$ & $3.95 \pm .103$ & $4.14 \pm .080$ & $4.29 \pm .167$ \\
\hline 90 & $4.24 \pm .138$ & $3.89 \pm .080$ & $4.11 \pm .063$ & $4.74 \pm .080$ & $4.34 \pm .115$ & $4.64 \pm .196$ \\
\hline Sig. & .000 & .065 & .428 & .000 & .360 & .276 \\
\hline
\end{tabular}

Data are presented as mean \pm SE of 3 replicates. $-S E$ : standard error. -Significant difference at $P<0.05$.SF: Soybean flour, MBP: Minced boiled potato

Table 4: Changes in Yeast and Mold Count of Sand Smelt Fish Products during Frozen Storage at $-18^{\circ} \mathrm{C}$

\begin{tabular}{|c|c|c|c|c|c|c|}
\hline \multirow{2}{*}{$\begin{array}{l}\text { Storage Period } \\
\text { (day) }\end{array}$} & \multicolumn{3}{|c|}{ Fish Burger } & \multicolumn{3}{|c|}{ Fish Finger } \\
\hline & Control & SF (15\%) & MBP (15\%) & Control & SF $(20 \%)$ & MBP (15\%) \\
\hline 0 & $2.01 \pm .092$ & $2.34 \pm .138$ & $2.61 \pm .115$ & $2.56 \pm .150$ & $2.71 \pm .173$ & $2.84 \pm .196$ \\
\hline 15 & ND & ND & ND & ND & ND & ND \\
\hline 30 & ND & ND & ND & ND & ND & ND \\
\hline 45 & ND & ND & ND & ND & ND & ND \\
\hline 60 & ND & ND & ND & ND & ND & ND \\
\hline 75 & ND & ND & ND & ND & ND & ND \\
\hline 90 & ND & ND & ND & ND & ND & ND \\
\hline Sig. & .000 & .000 & .000 & .000 & .000 & .000 \\
\hline
\end{tabular}

Data are presented as mean \pm SE of 3 replicates. $-S E$ : standard error. -Significant difference at $P<0.05 . N D$ : not detected. SF: Soybean flour, MBP: Minced boiled potato. 
samples were cooked by frying in vegetable oil (sunflower oil) before carrying out the evaluation. The panelists were asked to evaluate the sensory properties of the product in terms of color, taste, odor, texture and overall acceptability. Data collected from the evaluation was statistically analyzed and the results obtained are tabulated in Figures 1, 2, 3, 4 and 5.

\section{Color}

Color score values of sand smelt fish products during frozen storage are shown in Figure (1) The results indicated that color score values of the fresh control burger sample and those prepared by incorporation of $15 \%$ SF and $15 \%$ MBP were $6.2,9.0$ and 8.9 , respectively. Also, control finger sample and the samples formulated with adding $20 \%$ SF and $15 \%$ MBP scored color values of $6.6,7.9$ and 9.0, respectively. These results clearly show that colors of the formulated sand smelt products were significantly preferred by panelists.

The results given in Figure (1) showed no significant difference between SF and MBP formulated burger samples but in the case of fish fingers, MBP sample was significantly $(P<0.05)$ better. During frozen storage of sand smelt fish products color score values slightly declined. Meanwhile, the 90 days storage period showed no significant effect on the color of the different samples. The formulated burgers and fingers samples retained their good colors without undesirable changes over the entire period of frozen storage.

\section{Odor and Taste}

Data given in Figure $(2,3)$ show the changes in the odor and taste of sand smelt fish products during frozen storage. The result indicated that score values

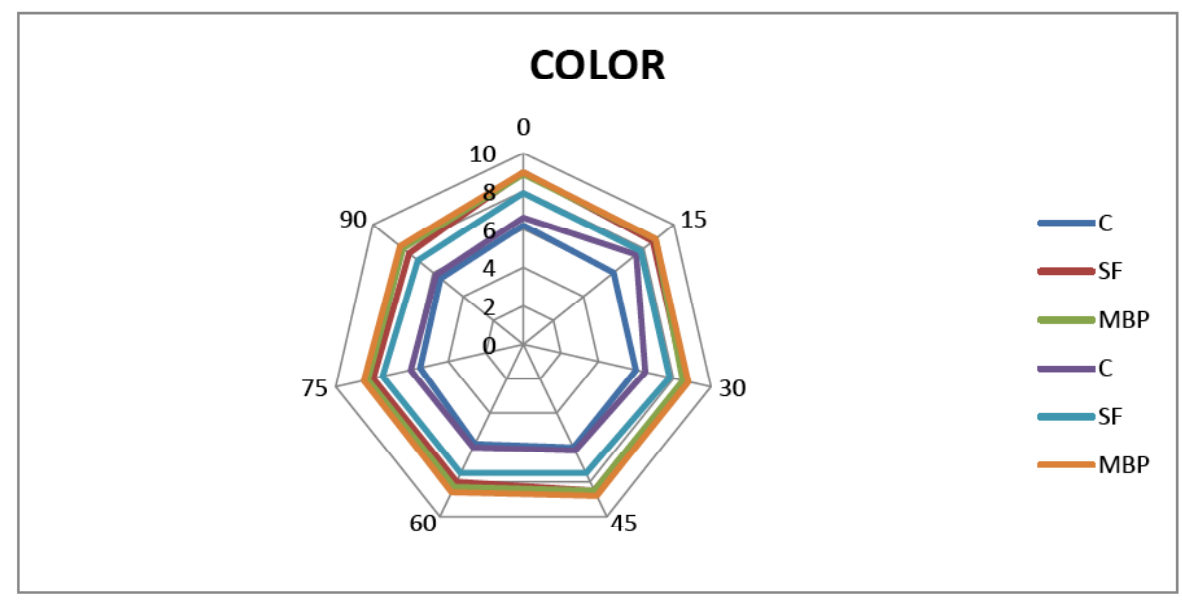

Figure 1: Changes in color of sand smelt fish products** during storage at $-18 \pm 1^{\circ} \mathrm{C}$. ** Samples were cooked by frying before sensory evaluation.

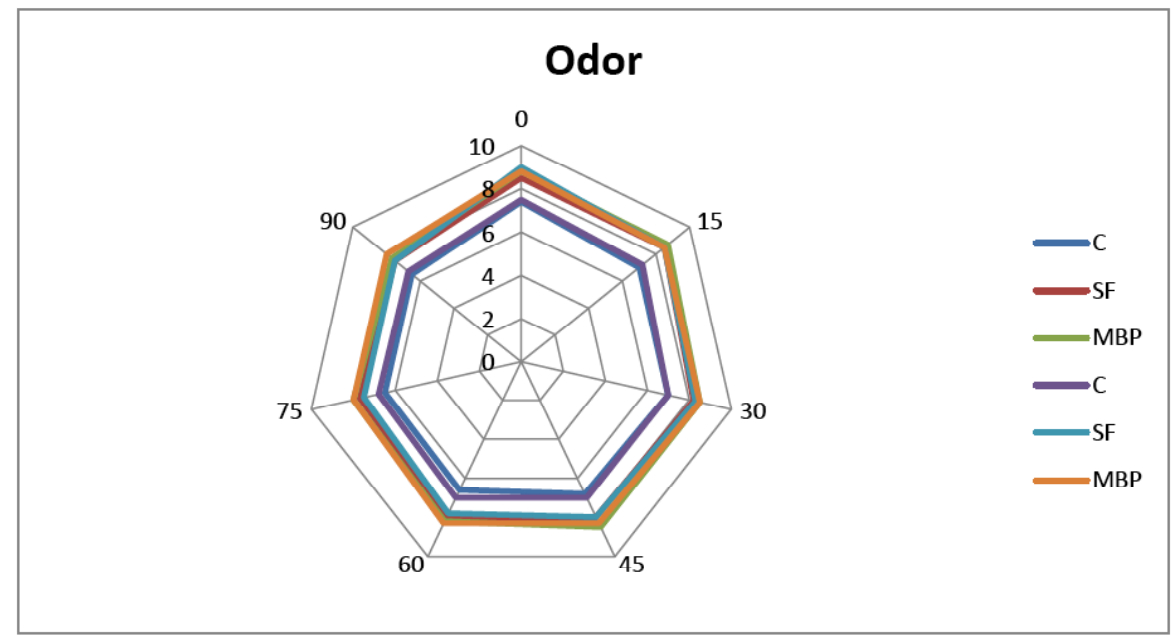

Figure 2: Changes in odor of sand smelt fish products ${ }^{* *}$ during storage at $-18 \pm 1^{\circ} \mathrm{C}$. **Samples were cooked by frying before sensory evaluation. 


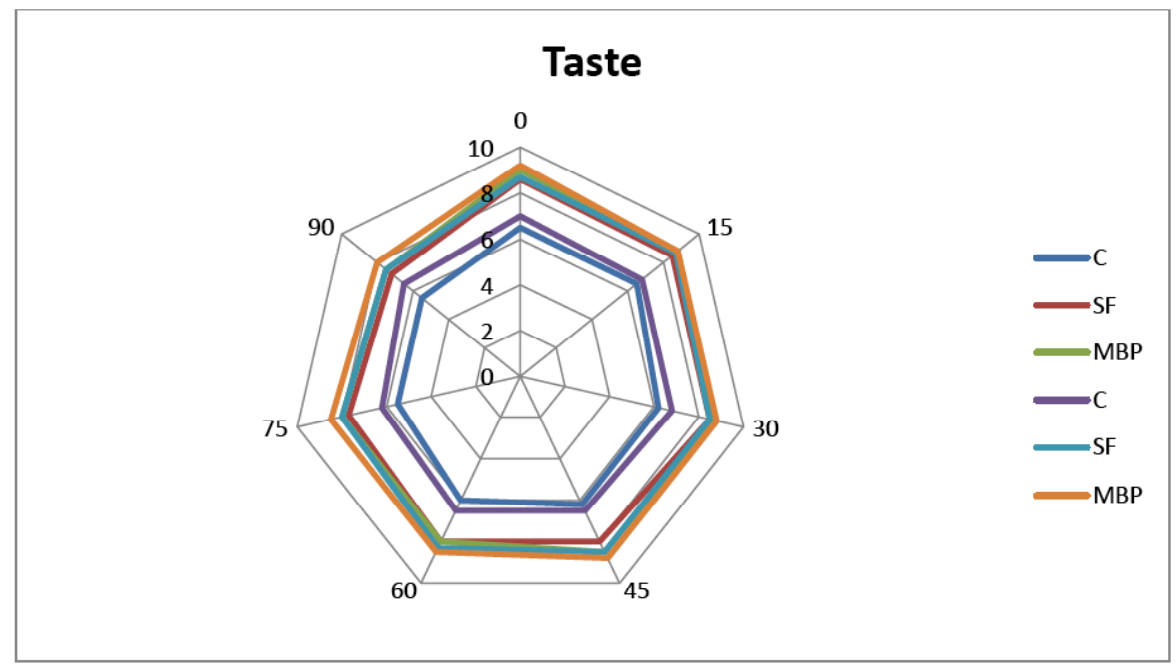

Figure 3: Changes in taste of sand smelt fish products ${ }^{* *}$ during storage at $-18 \pm 1^{\circ} \mathrm{C}$.

**Samples were cooked by frying before sensory evaluation.

for taste and odor of burger and fingers decreased as the storage period prolonged and the changes were more pronounced in control sample prepared without adding the filling materials. Odor and taste of burger control sample showed significant changes after 45- 60 days of frozen storage. Almost similar changes were recorded for control finger sample. On the other hand burger and finger samples formulated by incorporation of filling materials maintained their high good qualities for odor and taste over the entire 90 days of frozen storage.

\section{Texture}

Data given in Figure (4) Showed score values of texture of fish products made from sand smelt fish and their changes during frozen storage. Significant differences $(p<05)$ were found between the texture of burger and finger samples formulated with SF and MBP fillings and their control samples. Based on the score values, panelists evaluated texture of the formulated burger and fingers as excellent while textures of the control samples were fairly good.

It is important to consider the freeze - thaw stability of mince based fish products such as fish burgers and fingers during frozen storage. Data presented in Figure $\mathbf{X} \mathbf{D}$ showed that texture score values of sand smelt fish products slightly decreased during frozen storage. However, the formulated samples of burger and finger maintained their stable and good texture over the entire storage period, while control samples particularly for finger product showed an observed change during frozen storage. The common problem with frozen

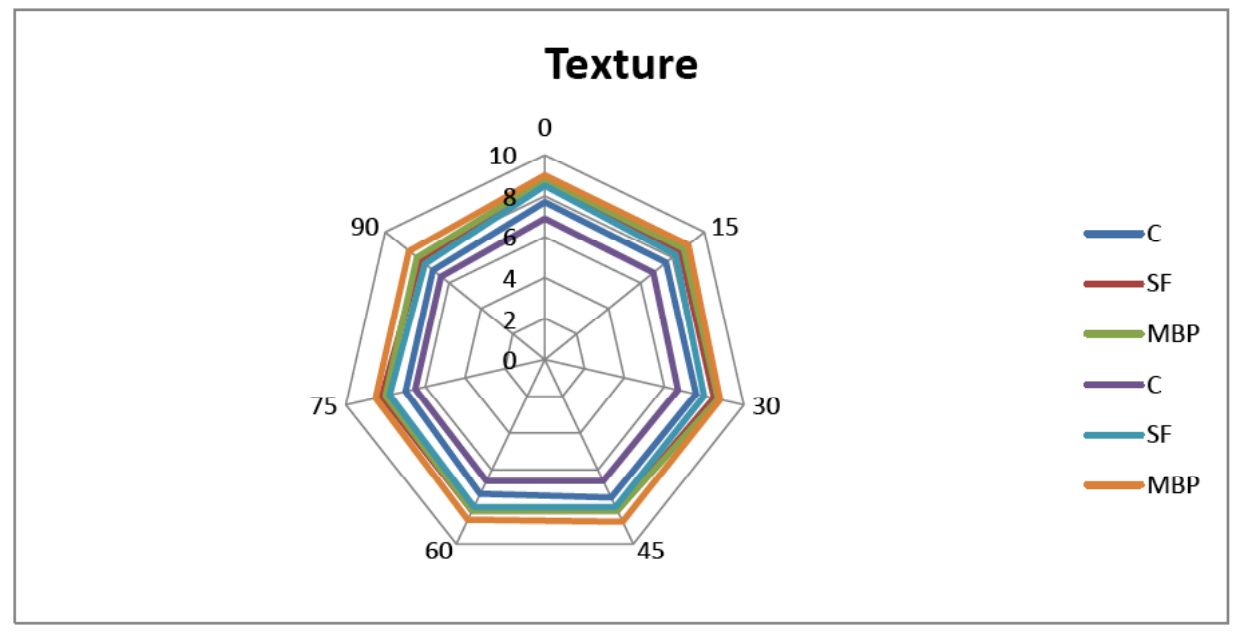

Figure 4: Changes in texture* of sand smelt fish products ${ }^{* *}$ during storage at $-18 \pm 1^{\circ} \mathrm{C}$.

**Samples were cooked by frying before sensory evaluation. 


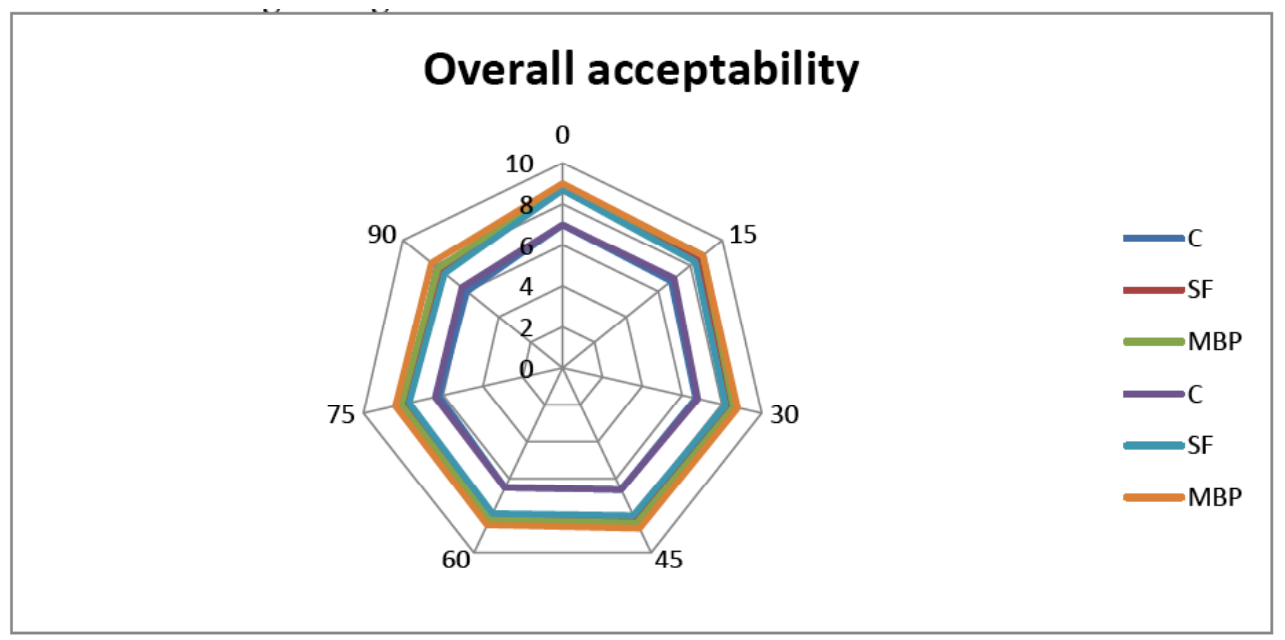

Figure 5: Changes in the overall acceptability* of sand smelt fish products ${ }^{* *}$ during storage at $-18 \pm 1^{\circ} \mathrm{C}$.

** Samples were cooked by frying before sensory evaluation.

storage of fish products is texture hardening and lack of moisture in the finish thawed products. This observation might be attributed to the drip separation accompanied by thawing process of the frozen product.

[22] Reported that ingredients such as soy protein and milk protein were found to have the ability to reduce the high freeze- thaw drip loss and maintaining the texture from hardening. Of course the rate of freezing is also essential to guaranty the small size of the ice crystals. The smaller the better to avoid cell disruption by ice crystals growth, with subsequent loss of cytoplasmic content as the drip loss.

\section{Overall Acceptability}

According to the results given in Figure (5) Score values of the overall acceptability showed that sand smelt fish products particularly those formulated with adding SF and MBP as filling materials had high good quality during the storage period of 90 days. This is the outcome of maintaining all the sensory quality attributes without undesirable changes during frozen storage. The undesirable quality changes in frozen fish products are associated with discoloration or brown stains, lipid oxidation and fishy odor development, and texture hardening or toughening. Score values for color, odor, taste and texture (Figure 1 to 5 ) indicated the high stability of these quality parameters of the formulated products made from sand smelt fish during frozen storage. Consequently, sand smelt fish products were liked by the panelists and they maintained the high acceptability during frozen storage for 90 days. This conclusion is supported by the results of microbiological examination of the products during the storage.

\section{CONCLUSION}

In conclusion fish burger and fish finger made from sand smelt fish showed high stability of quality parameters of the formulated products made from sand smelt fish with soy flour and minced potato fillings during frozen storage. Consequently, sand smelt fish products were liked by the panelists and a high acceptability was maintained during frozen storage for 90 days. This conclusion is supported by the good results of microbiological examination of the products during the storage, opening a good perspective for the production of these fish products to improve the sustainable use of fishery and increase the offer of good quality protein foods.

\section{REFERENCES}

[1] Gomma RAM. Studies on producing sausage from some fish types. M.Sc. Thesis, Fac. of Agric. Al-Azher Uni Egypt 2005.

[2] GAFRD. General Authority of Fish Resources Development. Fish Statics Year Book. Ministry of agriculture, Egypt 2016.

[3] Altun O. Morphological Variations Observed in Sand Smelt (Atherinaboyeri Risso, 1810). Populations Trend J Zool 1999; 23(3): 911-918.

[4] Speranza B, Corbo M, Conte A, Sinigaglia M, Del Nobile M. Microbiological and sensorial quality assessment of ready-tocook seafood products packaged under modified atmosphere. J of Food Science 2009; 74: 473-478. https://doi.org/10.1111/j.1750-3841.2009.01369.x

[5] Careche M, Herrero A, Rodriguez-Casado A, Del Mazo M, Carmona, P. Structural changes of hake (Merlucciusmerluccius L.) fillets: Effects of freezing and frozen storage. J of Agric and Food Chem 1999; 47(3): 952959.

https://doi.org/10.1021/jf9809481

[6] Kramer DE, Liston J. Seafood Quality Determination. pp. 677. New York: Elsevier Science Publishing, 1987.

[7] Sikorski ZE, Lolakowska A, Pan BS. The nutritive composition of the major groups of marine food organisms. 
In: Resources Nutritional Composition and Preservation (Sikorski ZE Ed). CRC Press-Inc, Boca Raton 1990; 30-52.

[8] Allam AG. Studies on storage ability of frozen bolti fish sample. Al-Azhar J Agric Res 2001; 14: 101-110.

[9] Australian Meat Standards Committee. microbiological guidelines to accompany the Australian standard as 46962002.

[10] Chandrasckhar TC, Mohite RR. Effect of fat coated sorbic acid (ECSA) and the shelf life of fish sausage stored at $10^{\circ} \mathrm{C}$ and ambient temperature. J Sea Food Export 1978; 10(11): 19-23.

[11] Çakli S, Taskaya L, Kisla D, Çelik U, Ataman CA, Cadun A, Kilinc $B$ et al. Production and quality of fish finger from different fish species.Eur. Food Res Technol 2005; 220: 526530

https://doi.org/10.1007/s00217-004-1089-9

[12] Tokur B, Ozkutuk S, Atıcı E, Ozyurt G, and Ozyurt CE. Chemical and sensory quality changes of fish fingers made from mirror carp (Cyprinuscarpio L, 1758) during frozen storage $\left(-18^{\circ} \mathrm{C}\right)$. Food Chem 2006; 99: 335-341. https://doi.org/10.1016/i.foodchem.2005.07.044

[13] Oxoid M. The Oxoid Manual of Culture Media and other Laboratory Services. Fourth Edition 1979.

[14] APHA. American Public Health Association. Compendium of methods for the microbiological examination of foods. Washington 1976.

[15] Barile LE, Milla AD, Reilly A, Viiiadsen A. Spoilage patterns of Mackerel (Rastrelligerfaughni, M.). bymesophilic and psychrophilic fish spoilage. FAO fish Rep 1985; 317: 146154.

[16] Woyewoda AD, Show Sj, Ke PJ, Burns BG. Recommended Laboratory Methods for assessment of fish quality. Canadian Technical Report of Fisheries and Aquatic Sci No 1448, 1986.

[17] ICMSF. Microorganisms in foods. The International Commission on Microbiological Specifications for Foods.Vol.1, Toronto, Canada 1978.

[18] Liston J. Microbiology in Fisheries Sciences. In: Connel, JJ. (Ed.), Advances in Fish Science and Technology. FNI Books, Farnham, Survey, UK 1980; pp: 138-157.

[19] Allam AG. Studies on storage ability of froenbolti fish samples. Al-Azhar Journal of Agriculture Research 2001; 14 101-110.

[20] Sarhan A MM. Quality aspects on some meat and fish product in local market M.Sc. Thesis, Faculty of Agriculture, Alazhr Univ. Egypt 2003.

[21] Izci L, Sengul B, Ali G. Production of fish chips from sand smelt (Atherinaboyeri, RISSO 1810) and Determination of some quality changes. Iranin Journal of Fisheries Sciences 2011; 10(2): 230-241.

[22] Yoon KS, Lee CM, Hufnagel LA. 'Effect of washing on the texture and microstructure of frozen fish mince' J Food Sci 1991; 56(2): 294-8 https://doi.org/10.1111/j.1365-2621.1991.tb05265.x

http://dx.doi.org/10.15379/2408-9826.2018.05.02.01

(c) 2018 El-Lahamy et al.; Licensee Cosmos Scholars Publishing House.

This is an open access article licensed under the terms of the Creative Commons Attribution Non-Commercial License

(http://creativecommons.org/licenses/by-nc/3.0/), which permits unrestricted, non-commercial use, distribution and reproduction in any medium, provided the work is properly cited. 